\title{
Asbestos Inhalation Induces Reactive Nitrogen Species and Nitrotyrosine Formation in the Lungs and Pleura of the Rat
}

\author{
Shogo Tanaka, ${ }^{\star}$ Nonghoon Choe, ${ }^{\star}$ David R. Hemenway, ${ }^{\ddagger}$ Sha Zhu, ${ }^{\S}$ Sadis Matalon, ${ }^{\S}$ and Elliott Kagan* \\ *Department of Pathology, Uniformed Services University of the Health Sciences, F. Edward Hébert School of Medicine, Bethesda, \\ Maryland 20814-4799; ${ }^{*}$ Department of Civil and Environmental Engineering, University of Vermont, Burlington, Vermont 05405; and \\ ${ }^{\S}$ Department of Anesthesiology, University of Alabama at Birmingham, Birmingham, Alabama 35233
}

\begin{abstract}
To determine whether asbestos inhalation induces the formation of reactive nitrogen species, three groups of rats were exposed intermittently over $2 \mathrm{wk}$ to either filtered room air (sham-exposed) or to chrysotile or crocidolite asbestos fibers. The rats were killed at 1 or $6 \mathrm{wk}$ after exposure. At $1 \mathrm{wk}$, significantly greater numbers of alveolar and pleural macrophages from asbestos-exposed rats than from sham-exposed rats demonstrated inducible nitric oxide synthase protein immunoreactivity. Alveolar macrophages from asbestos-exposed rats also generated significantly greater nitrite formation than did macrophages from shamexposed rats. Strong immunoreactivity for nitrotyrosine, a marker of peroxynitrite formation, was evident in lungs from chrysotile- and crocidolite-exposed rats at 1 and $6 \mathrm{wk}$. Staining was most evident at alveolar duct bifurcations and within bronchiolar epithelium, alveolar macrophages, and the visceral and parietal pleural mesothelium. Lungs from sham-exposed rats demonstrated minimal immunoreactivity for nitrotyrosine. Significantly greater quantities of nitrotyrosine were detected by ELISA in lung extracts from asbestos-exposed rats than from sham-exposed rats. These findings suggest that asbestos inhalation can induce inducible nitric oxide synthase activation and peroxynitrite formation in vivo, and provide evidence of a possible alternative mechanism of asbestos-induced injury to that thought to be induced by Fenton reactions. (J. Clin. Invest. 1998. 102:445-454.) Key words: crocidolite • chrysotile • nitric oxide $\bullet$ inducible nitric oxide synthase $\bullet$ nitrotyrosine
\end{abstract}

\section{Introduction}

It is well-recognized that occupational asbestos exposure is causally linked to a variety of clinical disorders afflicting the lungs and serous membranes including asbestosis, parietal pleural plaques, visceral pleural fibrosis, bronchogenic carci-

Address correspondence to Elliott Kagan, M.D., Department of Pathology, Uniformed Services University of the Health Sciences, F. Edward Hébert School of Medicine, 4301 Jones Bridge Road, Bethesda, MD 20814-4799. Phone: 301-295-3492; FAX: 301-295-1640; E-mail: ekagan@usuhs.mil

Received for publication 20 February 1998 and accepted in revised form 8 May 1998.

J. Clin. Invest.

(C) The American Society for Clinical Investigation, Inc. 0021-9738/98/07/0445/10 \$2.00

Volume 102, Number 2, July 1998, 445-454

http://www.jci.org noma, and diffuse malignant mesothelioma of the pleura and peritoneum $(1,2)$. Although all commercial varieties of asbestos are capable of fibrogenic and carcinogenic insult, there has been a long-standing debate regarding the relative potency of chrysotile (the serpentine type of asbestos that has been used most extensively in North America) versus crocidolite or amosite (amphibole) asbestos in this regard (3-5). Considerable attention has been focused on the putative role of reactive oxygen species in mediating asbestos-induced injury to the lungs and pleura via superoxide anions $\left(\mathrm{O}_{2}^{\overline{1}}\right),{ }^{1}$ hydrogen peroxide $\left(\mathrm{H}_{2} \mathrm{O}_{2}\right)$, and hydroxyl radicals $(\cdot \mathrm{OH})$ generated by modified Haber-Weiss (Fenton) reactions. Several studies have implicated the generation of reactive oxygen species in crocidolite-induced cellular cytotoxicity (6-8) and demonstrated that crocidolite-induced pulmonary inflammation and fibrosis in the rat was abrogated by the administration of polyethyleneconjugated catalase via an osmotic pump (7).

While generation of $\cdot \mathrm{OH}$ by Fenton reactions may explain some of the biologic effects of crocidolite (chemical composition: $\left.\mathrm{Na}_{2}\left[\mathrm{Fe}^{3+}\right]_{2}\left[\mathrm{Fe}^{2+}\right]_{3}\left[\mathrm{Si}_{8} \mathrm{O}_{22}\right][\mathrm{OH}]_{2}\right)$, it cannot account for the cytotoxic actions of chrysotile (chemical composition: $\left.\mathrm{Mg}_{3}\left[\mathrm{Si}_{2} \mathrm{O}_{5}\right][\mathrm{OH}]_{4}\right)$, which contains only $2-3 \%$ elemental iron $(9,10)$. Therefore, it is conceivable that asbestos fibers also may induce cellular injury via mechanisms not based on Fenton chemistry such as by the generation of reactive nitrogen species (RNS), as has been demonstrated in human acute lung injury and experimental models of granulomatous lung inflammation $(11,12)$. Some support for this contention is provided by studies which demonstrated that the addition of either crocidolite or chrysotile fibers to cytokine-stimulated cell cultures upregulated the production of nitric oxide $(\cdot \mathrm{NO})$ by rat alveolar macrophages (13) as well as by rat parietal pleural mesothelial cells (14). In the latter study, asbestos challenge also generated the formation of the highly reactive nitrogen compound, peroxynitrite anion $\left(\mathrm{ONOO}^{-}\right)$, a finding that was associated with cytotoxic changes within the pleural mesothelial cells (14). Furthermore, crocidolite fibers have been shown to induce the formation of the potentially carcinogenic modified DNA base, 8-hydroxy-2'-deoxyguanosine, in A549 human lung epithelial cells via an $\cdot \mathrm{NO}$-dependent pathway (15). In this study, using a defined in vivo model of prefibrotic, asbestos-induced injury in the rat $(7,16)$, we show for the first time that inhalation of asbestos fibers stimulates the production of RNS in the lungs and pleura. Furthermore, we demonstrate that chrysotile as well as crocidolite asbestos fibers can induce the formation of nitrotyrosine, a marker of $\mathrm{ONOO}^{-}$produc-

1. Abbreviations used in this paper: $\mathrm{BAL}$, bronchoalveolar lavage; iNOS, inducible nitric oxide synthase; $\cdot \mathrm{NO}$, nitric oxide; $\mathrm{O}_{\overline{2}}$, superoxide anion; $\cdot \mathrm{OH}$, hydroxyl radical; $\mathrm{ONOO}^{-}$, peroxynitrite anion; RNS, reactive nitrogen species; TNM, tetranitromethane. 
tion, at sites of asbestos fiber deposition as well as in the airway epithelium and pleural mesothelium.

\section{Methods}

Mineral dust samples and reagents. National Institute of Environmental Health Sciences (NIEHS, Research Triangle Park, NC) crocidolite fibers were a generous gift from Dr. Roy Rando (Tulane University School of Public Health, New Orleans, LA). Chrysotile fibers were obtained from the NIEHS. 3-nitro-L-tyrosine, 3-amino-L-tyrosine, $O$-phospho-L-tyrosine, tetranitromethane (TNM), bovine serum albumin fraction $\mathrm{V}$ (BSA), sodium deoxycholate, phenylmethylsulfonyl fluoride, aprotinin, pepstatin $\mathrm{A}$, sodium orthovanadate $\left(\mathrm{Na}_{3} \mathrm{VO}_{4}\right)$, $\mathrm{NaCl}$, EGTA, NaF, $\mathrm{Na}_{2} \mathrm{CO}_{3}, \mathrm{NaHCO}_{3}, \mathrm{KH}_{2} \mathrm{PO}_{4}$, and Harris's hematoxylin were purchased from Sigma Chemical Co. (St. Louis, MO). Tris base, Triton X-100, blocking reagent, and leupeptin were supplied by Boehringer Mannheim (Indianapolis, IN). Tween 20 was bought from Bio-Rad Laboratories (Hercules, CA), Diff-Quik ${ }^{\circledR}$ Stain Set was obtained from Baxter Healthcare (McGaw Park, IL), and sodium pentobarbital was purchased from Abbott Laboratories (North Chicago, IL). RPMI 1640, FBS, and PBS were supplied by Biofluids, Inc. (Rockville, MD).

Animals and inhalation exposure regimen. For the inhalation exposures, three groups of male Fischer-344 rats were placed in wholebody inhalation chambers and exposed to either NIEHS crocidolite asbestos fibers, NIEHS chrysotile asbestos fibers, or filtered room air (sham-exposed group). The rats in each group were comparably matched for age ( $56 \mathrm{~d}$ old) and size (mean weight for each group: $207 \mathrm{~g}$ ) before inhalation exposure. Using an established inhalation exposure protocol $(7,16,17)$, each group was exposed for $6 \mathrm{~h} / \mathrm{d}$ on $5 \mathrm{~d} / \mathrm{wk}$ over $2 \mathrm{wk}$. The rats were killed at 1 or $6 \mathrm{wk}$ after the cessation of exposure by the intraperitoneal administration of sodium pentobarbital (50 $\mathrm{mg} / \mathrm{kg}$ ), followed by exsanguination via the abdominal aorta.

Total fiber mass aerosol concentrations were measured on membrane filters using 25 -mm conductive cowl filter holders (Nucleopore, Carmel, CA) equipped with $0.8-\mu \mathrm{m}$ pore filters (DM-800; Gelman Sciences, Ann Arbor, MI) by standard gravimetric analysis. All total mass measurements were on a daily basis at the nose level of the exposed animals. The asbestos aerosols were generated using a modified Timbrell dust generator (BGI, Waltham, MA). Aerodynamic particle-size distributions were measured using a Sierra 8-stage cascade impactor (model 210; Andersen Instruments, Atlanta, GA) throughout the exposure period. For one series of experiments, in which the rats were killed $1 \mathrm{wk}$ after the cessation of exposure, the time-weighted exposure concentrations were as follows (mean $\pm \mathrm{SE}$ ): crocidolite $6.88 \pm 1.77 \mathrm{mg} / \mathrm{M}^{3}$; chrysotile $8.25 \pm 1.54 \mathrm{mg} / \mathrm{M}^{3}$. For another set of studies, in which the rats were killed $6 \mathrm{wk}$ after the cessation of exposure, the time-weighted exposure concentrations were as follows: crocidolite $7.65 \pm 1.08 \mathrm{mg} / \mathrm{M}^{3}$; chrysotile $9.24 \pm 1.55 \mathrm{mg} / \mathrm{M}^{3}$. These asbestos exposure levels were comparable with historic asbestos dust concentrations recorded in the workplace environment of asbestos mines and mills (18). Analysis of all impactor data indicated the following: crocidolite geometric mean diameter $=0.4 \mu \mathrm{m}$, geometric $\mathrm{SD}=3.8$; chrysotile geometric mean diameter $=0.5 \mu \mathrm{m}$, geometric $\mathrm{SD}=4.1$. Thus, the aerosols were very similar in aerodynamic size distributions and were highly respirable.

Collection of pleural and bronchoalveolar lavage (BAL) cells. BAL and pleural lavages were performed on rats killed $1 \mathrm{wk}$ after the termination of inhalation exposure. Lavages performed on the rats killed at $6 \mathrm{wk}$ after exposure had been used previously for another study (17). Consequently, immunohistochemical studies could only be performed on the lungs but not on the lavage cells from those three groups of exposed animals in the current study.

The technique of pleural lavage was performed, as described previously (17). Briefly, an 18-gauge Teflon cannula was inserted into the pleural cavity via a small diaphragmatic aperture and each pleural space was lavaged twice with $5 \mathrm{ml}$ of PBS, prewarmed to $37^{\circ} \mathrm{C}$. BAL was carried out by inserting a tube into the trachea, whereupon the lung was lavaged six times with $7 \mathrm{ml}$ of PBS, prewarmed to $37^{\circ} \mathrm{C}$, as described elsewhere (19). Cells were pelleted by centrifugation at $500 \mathrm{~g}$ and then resuspended in PBS for evaluation of viability (by trypan blue dye exclusion) and yield (by hemocytometry).

Cytospin preparations of BAL cells, comprising $>90 \%$ macrophages, were obtained using a Cytospin ${ }^{\circledR} 3$ cytocentrifuge (Shandon, Pittsburgh, PA) and were processed for differential cell counts (with Diff-Quik $^{\circledR}$ stain) and for immunocytochemical studies for inducible nitric oxide synthase (iNOS) protein expression. Enriched populations of pleural macrophages were obtained by adding crude pleural lavage cell populations $\left(3 \times 10^{6}\right.$ cells/well $)$ to 4 -well chamber slides (Lab-Tek, Naperville, IL) containing RPMI $1640+10 \%$ FBS, and incubating them in $5 \% \mathrm{CO}_{2}$ at $37^{\circ} \mathrm{C}$ for $2 \mathrm{~h}$. Thereafter, the cells were washed vigorously three times with PBS to remove nonadherent cells. Then the adherent cells, consisting of at least $77 \%$ macrophages, were used for immunocytochemical studies.

Measurement of $\mathrm{NO}_{2}^{-}$production by $\mathrm{BAL}$ cells. Washed BAL cells were obtained from rats that were killed $1 \mathrm{wk}$ after the termination of the inhalation exposure regimen. BAL cells from two to three rats per exposure group were pooled, suspended in DMEM $+10 \%$ FBS, and added to 24-well tissue culture plates $\left(2 \times 10^{6}\right.$ cells/well $)$. After allowing the cells to attach for $1 \mathrm{~h}$ at $37^{\circ} \mathrm{C}$, nonadherent cells were removed, $1 \mathrm{ml}$ of DMEM was added, and the adherent cells were incubated for an additional $24 \mathrm{~h}$ at $37^{\circ} \mathrm{C}$. Conditioned medium samples were collected and analyzed for $\mathrm{NO}_{2}^{-}$content, the oxidation product of $\cdot \mathrm{NO}$, by the Griess reaction (20).

Processing of tissues for histology and immunohistochemistry. The lungs, diaphragms, and chest walls were excised from four rats in each exposure group that were killed at 1 or $6 \mathrm{wk}$ after the cessation of the exposure regimen. None of these animals had been subjected to BAL at the time of killing. The diaphragm and chest wall samples were fixed in $10 \%$ neutral buffered formalin. The lungs were inflation-fixed in situ by the intratracheal instillation of $\sim 5 \mathrm{ml}$ of $10 \%$ neutral buffered formalin at a pressure of $20 \mathrm{~cm}$. Sagittal sections then were prepared of the left lung with sharp razor blades. All tissue samples were embedded in paraffin and routinely processed for histologic and immunohistochemical analyses, for which 5 - $\mu \mathrm{m}$-thick sections were prepared. Lung histology was evaluated on sections stained with hematoxylin and eosin and with the trichrome stain.

Immunostaining for ED1 antigen, iNOS protein, and nitrotyrosine. Immunostaining was performed on histologic sections and on lavage cell preparations. Before performing immunocytochemical studies, the BAL cells on cytospin slides and the pleural lavage adherent cells on 4-well chamber slides were fixed with acetone for 10 min at ambient temperature. To inhibit endogenous peroxidase activity, the lavage cells (which had strong endogenous activity) were incubated with $3 \% \mathrm{H}_{2} \mathrm{O}_{2}$ in absolute methanol, whereas the tissue sections (which manifested lesser endogenous activity) were incubated with $0.3 \% \mathrm{H}_{2} \mathrm{O}_{2}$ in methanol for $30 \mathrm{~min}$ at ambient temperature. Specific immunocytochemical studies were performed using a monoclonal anti-iNOS protein antibody (1:20 dilution; Transduction Laboratories, Lexington, KY), a monoclonal anti-rat mononuclear phagocyte (ED1) antibody (1:50 dilution; PharMingen, San Diego, $\mathrm{CA}$ ), and a polyclonal antinitrotyrosine antibody (1:50 dilution; Upstate Biotechnology, Lake Placid, NY) as primary antibodies for $1 \mathrm{~h}$ at ambient temperature. Since the anti-iNOS protein and anti-ED1 antibodies were not suitable for use in immunohistochemical studies on formalin-fixed sections, they were used exclusively for studies on BAL and pleural lavage cells. However, the antinitrotyrosine antibody was used on tissue sections because nitrotyrosine immunoreactivity can be readily demonstrated in formalin-fixed tissue (21). The cell preparations and sections were labeled using a Universal DAKO LSBA $^{\circledR} 2$ kit containing an appropriate, biotinylated secondary antibody and streptavidin-conjugated peroxidase (DAKO, Carpinteria, CA). For immunocytochemical visualization, 3,3'-diaminobenzidine (Sigma Chemical Co.) was used as a substrate, and the cell preparations and sections were counterstained with Harris's hematoxylin. As 
a negative control, the appropriate specific primary antibody was omitted, and $1 \%$ blocking reagent was substituted. To confirm the specificity of the antinitrotyrosine antibody, the antiserum was incubated with either $10 \mathrm{mM} 3$-nitro-L-tyrosine, $10 \mathrm{mM} 3$-amino-L-tyrosine, or $10 \mathrm{mM} O$-phospho-L-tyrosine in $0.05 \mathrm{M}$ Tris-HCl buffer immediately before the addition of the primary antibody to the tissue sections. As an additional negative control, tissue sections were incubated with $10 \%$ normal rabbit serum in Tris buffer instead of the antinitrotyrosine antibody.

Quantitation of immunostained macrophages. Quantitative immunostaining for ED1 antigen, a specific phenotypic marker for rat mononuclear cells (22), and for iNOS protein expression was performed by counting the fraction of immunoreactive BAL and adherent pleural cells in 10 randomized microscopic fields at a magnification of 400. Since alveolar macrophages were readily identified in histologic sections, macrophage quantitation for nitrotyrosine immunoreactivity was performed by counting 400 consecutive alveolar macrophages in tissue sections at a magnification of 400 and then determining the proportion of immunoreactive cells.

Quantitation of lung nitrotyrosine content. Rat lung nitrotyrosine content was quantified in three rats from each exposure group that had been killed at 1 wk after exposure had ceased and that had not been subjected to BAL. For this purpose, the entire left lung was removed, placed in PBS on ice, and ground into a fine mesh using a vortex-style tissue mixer. After centrifugation at $3,000 \mathrm{~g}$ for $5 \mathrm{~min}$ at $4^{\circ} \mathrm{C}$ and removal of the supernatant, the tissue fragments were dispersed in five volumes of ice-cold tissue lysis buffer comprising the following: $50 \mathrm{mM}$ Tris- $\mathrm{HCl}, \mathrm{pH} 7.4,1 \%$ Triton $\mathrm{X}-100,0.25 \%$ sodium deoxycholate, $150 \mathrm{mM} \mathrm{NaCl}, 1 \mathrm{mM}$ EGTA, $1 \mathrm{mM}$ phenylmethylsulfonyl fluoride, $1 \mu \mathrm{g} / \mathrm{ml}$ aprotinin, $1 \mu \mathrm{g} / \mathrm{ml}$ leupeptin, $1 \mu \mathrm{g} / \mathrm{ml}$ pepstatin, $1 \mathrm{mM}$ $\mathrm{Na}_{3} \mathrm{VO}_{4}$, and $1 \mathrm{mM} \mathrm{NaF}$. Then the samples were sheared by sonication and stored overnight on ice. After centrifugation at 10,000 $\mathrm{g}$ for $10 \mathrm{~min}$ at $4^{\circ} \mathrm{C}$, the supernatant was collected and assayed for lung protein and nitrotyrosine content. The protein concentrations of the lung sample supernatants were determined using a Bio-Rad Protein Assay Kit I (Bio-Rad Laboratories, Hercules, CA).

Quantitation of rat lung nitrotyrosine levels was performed by a modification of a previously published ELISA procedure (23). A nitrated protein solution was prepared for use as a standard by incubating $0.1 \%(1 \mathrm{mg} / \mathrm{ml}) \mathrm{BSA}$ in $50 \mathrm{mM} \mathrm{K \textrm {H } _ { 2 }} \mathrm{PO}_{4}$ at a $\mathrm{pH}$ of 7.4 for $30 \mathrm{~min}$ at $37^{\circ} \mathrm{C}$ with $1 \mathrm{mM}$ TNM, a very efficient nitrating agent (24). After adjusting the $\mathrm{pH}$ to 10.0 with $3 \mathrm{M} \mathrm{NaOH}$, the amount of nitrotyrosine present in the TNM-treated BSA solution was measured at $430 \mathrm{~nm}$ $\left(\epsilon_{\mathrm{m}}=4,400 \mathrm{M}^{-1} \mathrm{~cm}^{-1}\right)$ and expressed as nanomoles of nitrotyrosine per milligram of BSA. Subsequently, a stock solution of the TNMtreated BSA was diluted with $0.1 \mathrm{M} \mathrm{Na}_{2} \mathrm{CO}_{3}-\mathrm{NaHCO}_{3}$ coating buffer at a $\mathrm{pH}$ of 9.6. These standard samples, along with tissue samples from the lungs of sham-exposed and asbestos-exposed rats $(100 \mu \mathrm{l}$; $100 \mu \mathrm{g} / \mathrm{ml}$ ), were applied to Immulon 2 ELISA plates (Dynatech, Chantilly, VA) and allowed to bind for $1 \mathrm{~h}$ at $37^{\circ} \mathrm{C}$. After nonspecific binding sites were blocked with $1 \%$ BSA in PBS, the wells were incubated for $90 \mathrm{~min}$ at $37^{\circ} \mathrm{C}$ with a mouse $\mathrm{IgG}$ monoclonal antinitrotyrosine primary antibody (Upstate Biotechnology), diluted 1:200, and, subsequently, for $30 \mathrm{~min}$ at $37^{\circ} \mathrm{C}$ with a peroxidase-conjugated goat anti-mouse IgG secondary antibody (Kirkegaard \& Perry Laboratories, Inc., Gaithersburg, MD), diluted 1:1,000. After washing the plates, the peroxidase reaction product was generated using a TMB Microwell Peroxidase Substrate (Kirkegaard \& Perry Laboratories, Inc.). The reaction plate was incubated for $10 \mathrm{~min}$ at ambient temperature and its optical density was measured at $650 \mathrm{~nm}$. We calculated the amount of nitrotyrosine content per milligram of protein by relating the optical absorbance values of the nitrated BSA standards measured by ELISA to the levels of nitrotyrosine per milligram of BSA as determined spectrophotometrically. Nitrotyrosine content of lung samples was expressed as picomoles of nitrotyrosine per milligram of protein.

Statistical analysis. Quantitative data are expressed as mean $\pm \mathrm{SE}$ of three experiments per group. The statistical significance of the data was determined by the Student's $t$ test.

\section{Results}

Total yield and composition of lavage cells. Table I shows the total cell yield, viability, and macrophage fraction obtained by BAL and pleural lavage from rats in each exposure group at $1 \mathrm{wk}$ after the termination of exposure. Although there were no significant differences between the number of BAL cells recovered from rats in the three exposed groups, significantly greater numbers of total pleural cells and pleural macrophages were recovered from asbestos-exposed rats than from shamexposed animals.

iNOS protein expression in BAL and pleural lavage cells. As shown in Fig. 1, at $1 \mathrm{wk}$ after the cessation of exposure significantly higher percentages of iNOS-positive BAL cells were noted after both types of asbestos exposure than after sham exposure. More than $90 \%$ of these cells were macrophages and significantly greater total numbers of iNOS-positive alveolar macrophages were recovered from crocidolite- $(1.51 \pm 0.13 \times$ $10^{6}$ cells/rat; $P<0.05$ vs. sham-exposed) or chrysotile-exposed rats $\left(1.89 \pm 0.11 \times 10^{6}\right.$ cells $/$ rat $P<0.005$ vs. sham-exposed $)$ than from sham-exposed rats $\left(1.02 \pm 0.13 \times 10^{6}\right.$ cells $/$ rat $)$. Similar observations were noted in pleural lavage cells (Fig. 2) which comprised $\sim 77-80 \%$ macrophages (Table II).

$\mathrm{NO}_{2}^{-}$production by $\mathrm{BAL}$ cells. The amounts of $\mathrm{NO}_{2}^{-}$ produced in 24-h cultures of BAL cells obtained from the three exposed groups of rats at $1 \mathrm{wk}$ after exposure are shown in Fig. 1. Distinct differences between the groups were ob-

Table I. Total Cell Yield and Total Macrophages Recovered by BAL and Pleural Lavage from Asbestos-exposed and Sham-exposed Rats

\begin{tabular}{|c|c|c|c|c|c|c|}
\hline \multirow[b]{2}{*}{ Exposure group } & \multicolumn{3}{|c|}{ BAL cell viability and yield/rat $\left(\times 10^{6}\right)^{*}$} & \multicolumn{3}{|c|}{ Pleural lavage cell viability and yield/rat $\left(\times 10^{6}\right)^{\ddagger}$} \\
\hline & Viability & Total cells $s^{\S}$ & Total macrophages $^{\S}$ & Viability & Total cells $s^{\S}$ & Total macrophages ${ }^{\S}$ \\
\hline & $\%$ & & & $\%$ & & \\
\hline Sham & $89 \pm 1.3$ & $6.3 \pm 0.83$ & $5.87 \pm 0.77$ & $97 \pm 1.7$ & $10.64 \pm 0.45$ & $7.91 \pm 0.34$ \\
\hline Crocidolite & $90 \pm 2.2$ & $5.65 \pm 0.47$ & $5.34 \pm 0.45$ & $96 \pm 0.3$ & $14.71 \pm 0.45 \|$ & $10.84 \pm 0.33^{\|}$ \\
\hline Chrysotile & $94 \pm 0.4$ & $6.85 \pm 0.41$ & $6.32 \pm 0.38$ & $96 \pm 0.5$ & $12.54 \pm 0.4^{\pi}$ & $9.03 \pm 0.29 * *$ \\
\hline
\end{tabular}

${ }^{*} n=3$ rats/group. ${ }^{\ddagger} n=10$ rats/group. ${ }^{\S}$ Mean \pm SE. ${ }^{\|} P<0.001$ compared with sham-exposed group. ${ }^{\natural} P<0.01$ compared with sham-exposed group. $* * P<0.05$ compared with sham-exposed group. 


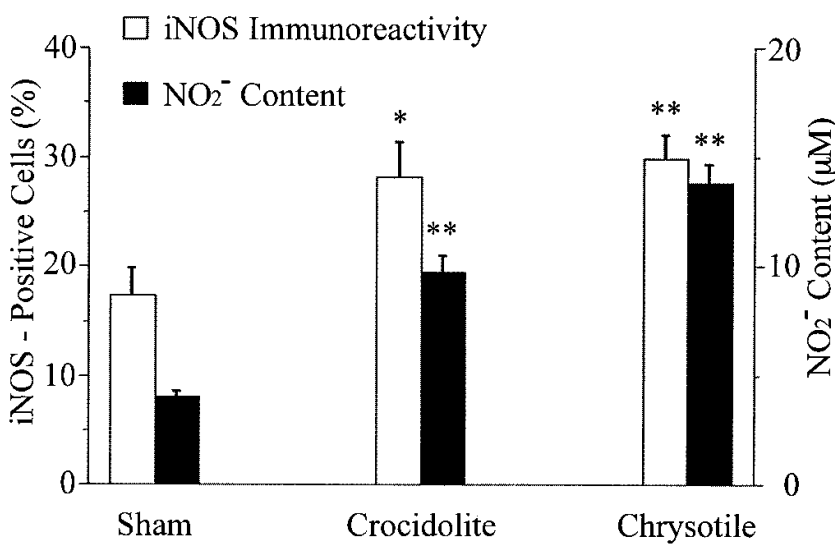

Figure 1. Evidence of iNOS activation in alveolar macrophages from sham-exposed and asbestos-exposed rats. Left ordinate shows the proportions of alveolar macrophages demonstrating iNOS immunoreactivity $(n=3)$. Right ordinate shows the production of $\mathrm{NO}_{2}^{-}$by cultured alveolar macrophages $(n=10)$. Values represent mean \pm SE ${ }^{*} P<0.05$ compared with sham-exposed rats; ${ }^{* *} P<0.01$ compared with sham-exposed rats.

served, as reflected by significantly greater $\mathrm{NO}_{2}^{-}$formation in BAL cell cultures from asbestos-exposed rats than from shamexposed animals. Notably, chrysotile inhalation also was associated with significantly greater $\mathrm{NO}_{2}^{-}$production than was evident after crocidolite exposure $(P<0.001)$.

Nitrotyrosine expression in lungs. Examination of hematoxylin and eosin-stained sections of the lungs, chest wall, and diaphragms of sham-exposed rats revealed no histologic abnormalities. In contrast, the lungs of crocidolite- and chrysotile-exposed rats demonstrated prominent thickening of alveolar duct bifurcations with focal aggregations of macrophages at
Table II. Proportions of ED1-positive Cells and Total iNOS-positive Macrophage Yield in Pleural Lavages from Asbestos-exposed and Sham-exposed Rats*

\begin{tabular}{|c|c|c|c|}
\hline \multirow[b]{2}{*}{ Exposure group } & \multicolumn{3}{|c|}{ Pleural lavage cells ${ }^{\ddagger}$} \\
\hline & $\begin{array}{l}\text { ED1-positive } \\
\text { cells }^{\S}\end{array}$ & $\begin{array}{l}\text { iNOS-positive } \\
\text { cells }^{\S}\end{array}$ & $\begin{array}{c}\text { No. of iNOS-positive } \\
\text { macrophages/rat }\left(\times 10^{5}\right)^{\S}\end{array}$ \\
\hline & $\%$ & $\%$ & \\
\hline Sham & $79.5 \pm 0.8$ & $4.41 \pm 0.55$ & $3.49 \pm 0.15$ \\
\hline Crocidolite & $77.8 \pm 0.8$ & $8.56 \pm 0.15^{\|}$ & $9.27 \pm 0.91^{\mathscr{T}}$ \\
\hline Chrysotile & $78.8 \pm 0.7$ & $9.59 \pm 0.11^{\mathscr{T}}$ & $8.66 \pm 0.87^{9}$ \\
\hline
\end{tabular}

*Immunocytochemistry performed after nonadherent cells were eliminated. ${ }^{\ddagger} n=10$ rats/group. ${ }^{\S}$ Mean \pm SE. ${ }^{\|} P<0.0005$ compared with sham-exposed group. ${ }^{\text {II }} P<0.0001$ compared with sham-exposed group.

these sites, as has been described previously after asbestos inhalation $(25,26)$. These histologic findings were observed in lung sections obtained at both 1 and $6 \mathrm{wk}$ after the cessation of asbestos exposure. However, no evidence of parenchymal, visceral pleural, or parietal pleural fibrosis was detected in the lungs of any of the exposed rats on Masson's trichromestained sections.

Lung sections from asbestos-exposed rats also displayed strong immunoreactivity for the presence of nitrotyrosine at both 1 and 6 wk after the termination of exposure. Thus, diffusely positive cytoplasmic immunostaining for nitrotyrosine was evident in the region of alveolar duct bifurcations, both within alveolar ductal epithelium and within underlying interstitial cells (Fig. 3). These findings were apparent after exposure to crocidolite (Fig. 3, $A$ and $B$ ) as well as after chrysotile exposure (Fig. 3, $C-E$ ). Strong immunoreactivity for nitrotyrosine also was observed within the apical portions of the cyto-

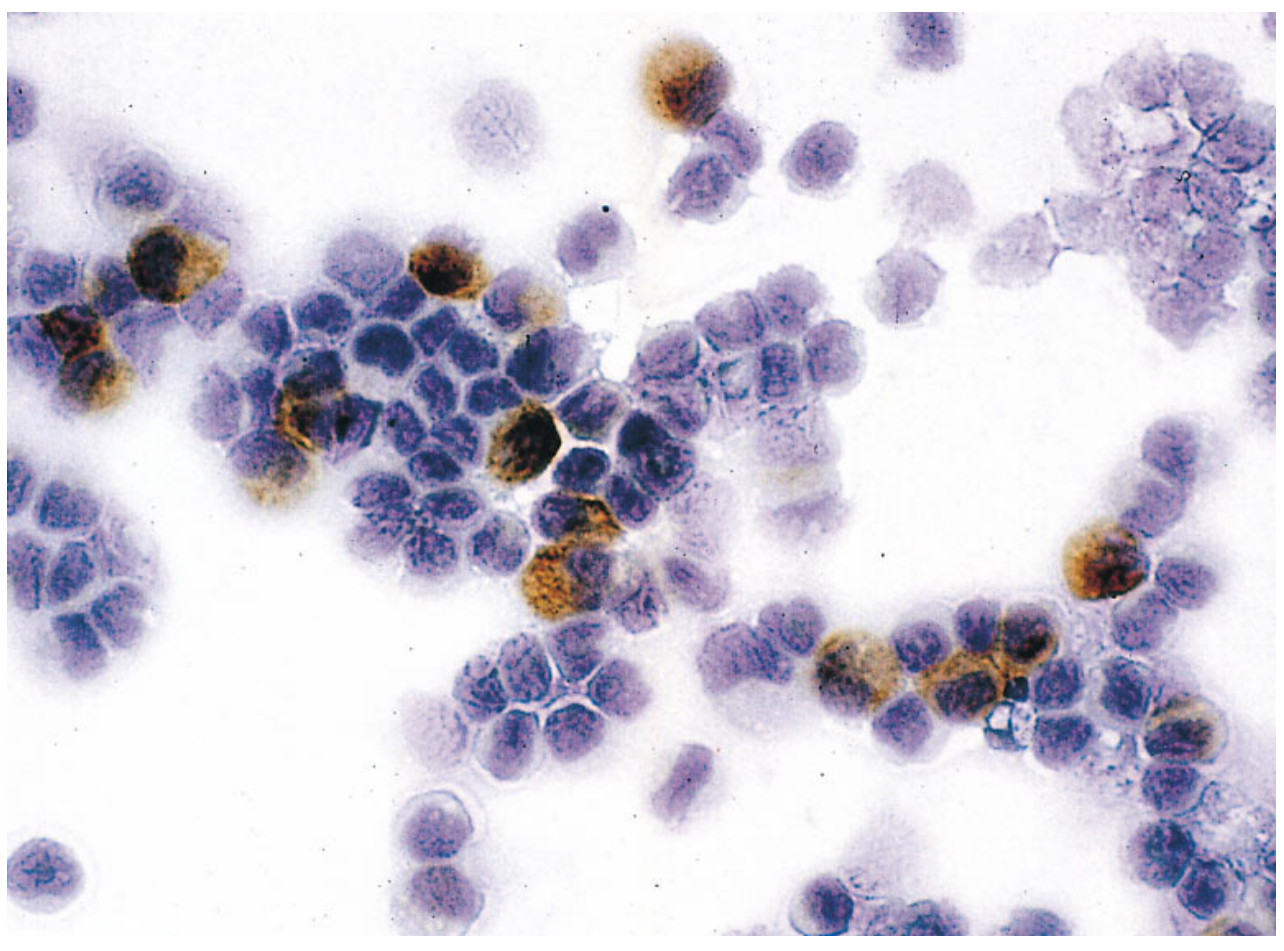

Figure 2. Immunoperoxidase staining for iNOS protein in pleural macrophages from a chrysotile-exposed rat at $1 \mathrm{wk}$ after the cessation of exposure. Original magnification, $\times 150$. 

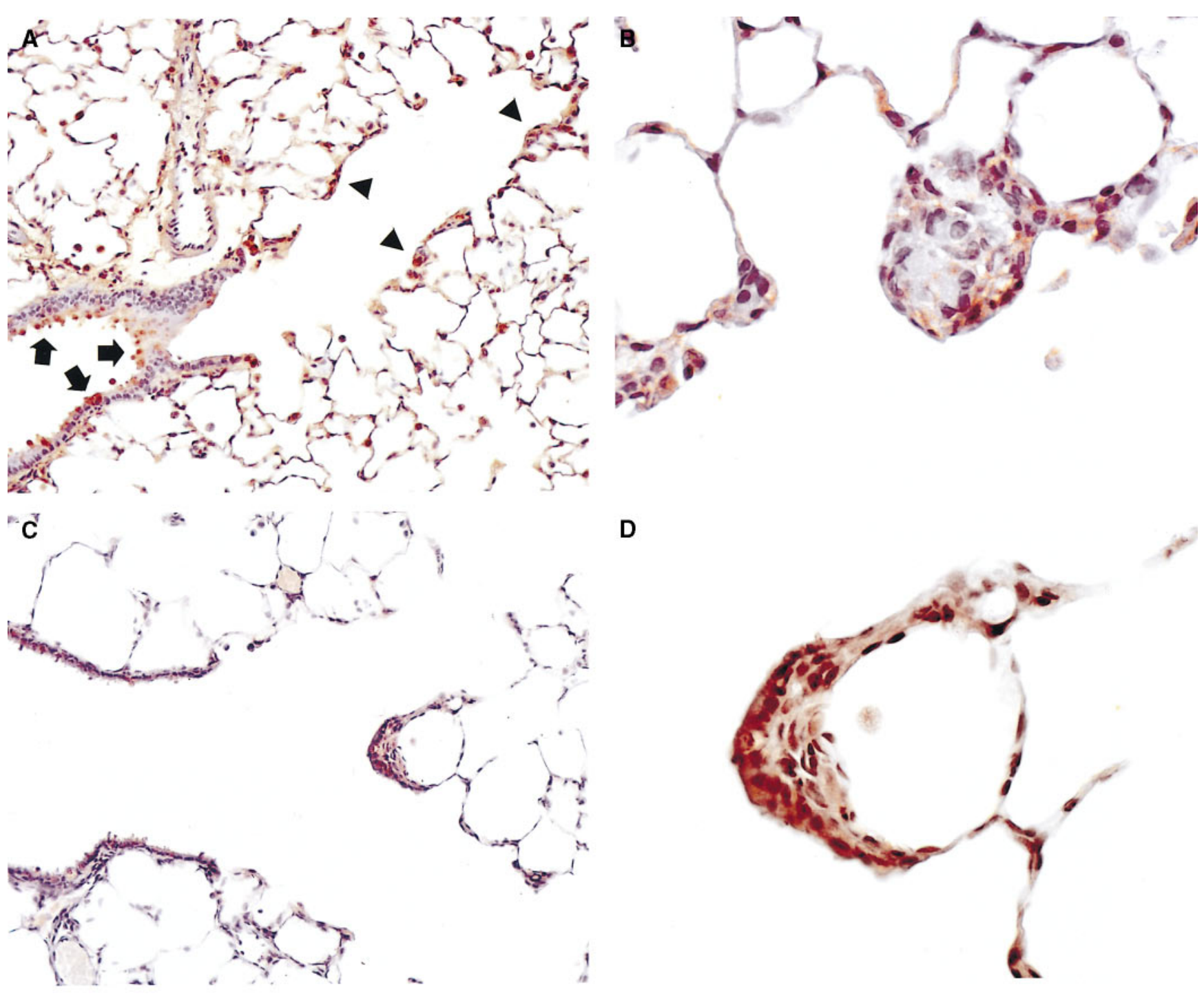

D
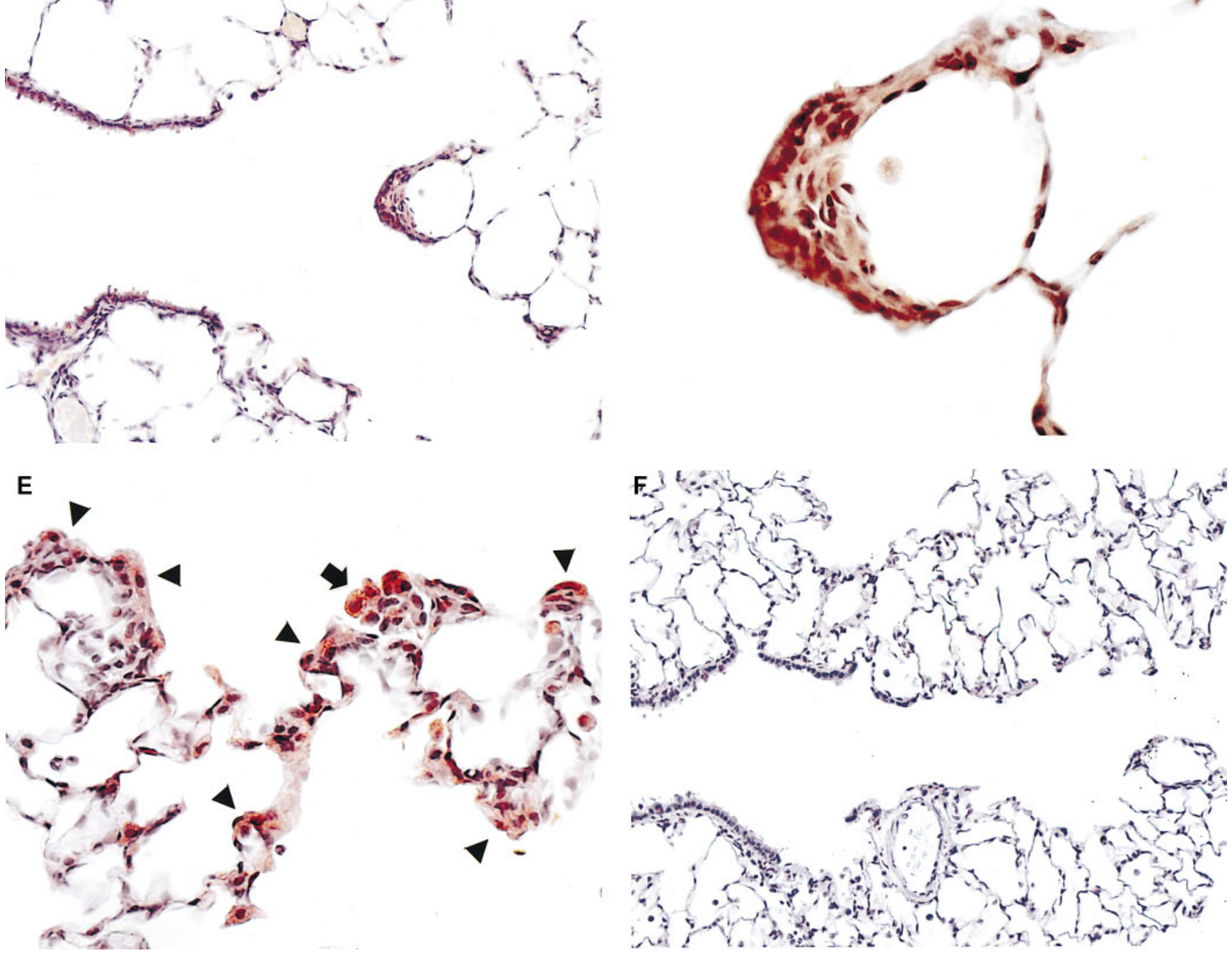

Figure 3. Immunoperoxidase staining for nitrotyrosine in lung sections from asbestos-exposed and sham-exposed rats at $1 \mathrm{wk}$ after the cessation of exposure. $(A)$ The bronchiolar epithelium (arrows) and alveolar duct region (arrowheads) of a crocidolite-exposed rat show positive immunostaining for nitrotyrosine. Original magnification, $\times 50$. (B) Immunoreactivity for nitrotyrosine is observed in some of the interstitial cells and alveolar ductal epithelium of a crocidolite-exposed rat. Original magnification, $\times 150$. $(C)$ The bronchiolar epithelium and alveolar duct bifurcation region from a chrysotile-exposed rat show positive immunoreactivity for nitrotyrosine. Original magnification, $\times 50$. $(D)$ Positive immunostaining for nitrotyrosine is evident in many of the interstitial cells and in the alveolar ductal epithelium of a chrysotile-exposed rat. 


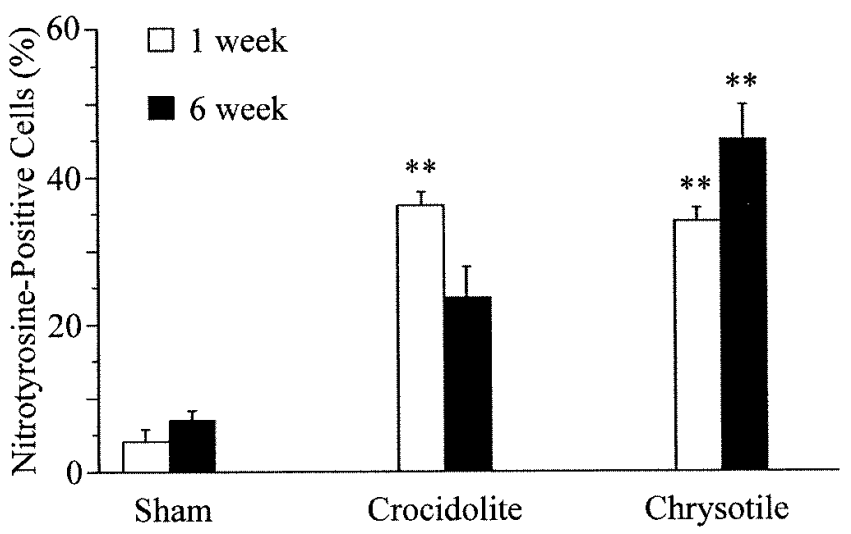

Figure 4. Proportions of alveolar macrophages demonstrating immunoreactivity for nitrotyrosine in lung sections from asbestos-exposed and sham-exposed rats at 1 and $6 \mathrm{wk}$ after the cessation of exposure. Values represent mean $\pm \operatorname{SE}(n=4)$. $* * P<0.01$ compared with sham-exposed rats.

plasm of the bronchiolar epithelium in both crocidoliteexposed (Fig. $3 A$ ) and chrysotile-exposed rats (Figs. $3 C$, and see Fig. $6 A$ ). In contrast, only faint immunoreactivity for nitrotyrosine was detected within occasional bronchiolar epithelial cells of sham-exposed rats at $1 \mathrm{wk}($ Fig. $3 F$ ) and $6 \mathrm{wk}$ after exposure. A small proportion of alveolar macrophages in lung sections from sham-exposed animals displayed cytoplasmic immunostaining for nitrotyrosine (Fig. 4). However, the proportions of nitrotyrosine-positive alveolar macrophages detected in rat lung sections increased approximately four- to ninefold after both types of asbestos inhalation (Fig. 4). Cytoplasmic immunostaining of the alveolar macrophages in the lungs of exposed animals was intense (Figs. 3-5) and was seen at $1 \mathrm{wk}$ and for as long as $6 \mathrm{wk}$ after exposure had ceased (Fig. $4)$. Both crocidolite- and chrysotile-exposed rats also manifested focal areas of strong cytoplasmic immunoreactivity for nitrotyrosine in the visceral mesothelium (Fig. 5, $A-C$ ) as well as in the parietal pleural mesothelial cells lining the diaphragm (Fig. 5, D) and chest wall. Again, immunostaining for nitrotyrosine was evident within pleural mesothelial cells at $1 \mathrm{wk}$ (Fig. 5, $A$ and $B$ ) and at 6 wk (Fig. $5 C$ ) after the termination of exposure. No mesothelial immunoreactivity for nitrotyrosine was detected in tissue sections from sham-exposed rats.

Immunospecificity of the primary antibody for nitrotyrosine was confirmed when immunoreactivity of the tissues was abolished by absorption of antinitrotyrosine activity with soluble $10 \mathrm{mM}$ nitrotyrosine (Fig. 6 C). In contrast, neither $10 \mathrm{mM}$ aminotyrosine nor $10 \mathrm{mM}$ phosphotyrosine inhibited the binding of the antinitrotyrosine antibody (data not shown). This is in agreement with what has been described previously $(11,27)$. Furthermore, no tissue immunoreactivity was de-
Table III. Lung Nitrotyrosine Content Determined by ELISA in Left Lung Lobes from Asbestos-exposed and Sham-exposed Rats at 1 wk after the Cessation of Exposure

\begin{tabular}{lc}
\hline \multicolumn{1}{c}{ Exposure group* } & Lung nitrotyrosine concentration ${ }^{*}$ \\
\hline & (pmol/mg protein $)$ \\
Sham-exposed & $31 \pm 3.6$ \\
Crocidolite-exposed & $59 \pm 5^{\S}$ \\
Chrysotile-exposed & $84 \pm 12^{\|}$ \\
\hline
\end{tabular}

${ }^{*} n=3$ rats/group. ${ }^{\ddagger}$ Mean \pm SE. ${ }^{\S} P<0.05$ compared with sham-exposed group. $\| P<0.01$ compared with sham-exposed group.

tected when $10 \%$ normal rabbit serum was substituted as the primary antibody (Fig. $6 B$ ).

Quantitation of lung nitrotyrosine content by ELISA. The total protein content of samples extracted from the left lung lobes of rats in each exposure group ranged from 2.11 to 2.23 $\mathrm{mg}$. Significantly higher concentrations of nitrotyrosine were detected in the lungs of crocidolite- and chrysotile-exposed rats than in sham-exposed animals (Table III).

\section{Discussion}

Our data show that inhalation of either chrysotile or crocidolite asbestos fibers results in increased levels of stable by-products of $\cdot \mathrm{NO}$ in BAL cells and the formation of nitrotyrosine within the lungs and pleura. Thus, 1 wk after the cessation of exposure, alveolar macrophage iNOS protein immunoreactivity and $\mathrm{NO}_{2}^{-}$production were significantly greater after asbestos inhalation than after sham exposure. Notably, $\mathrm{NO}_{2}^{-}$production in BAL cells was significantly greater after chrysotile inhalation than after crocidolite exposure, a finding that is consistent with a similar observation noted previously in rat pleural lavage cells (17).

Both groups of asbestos-exposed rats also manifested positive cytoplasmic immunostaining for nitrotyrosine in the region of thickened alveolar duct bifurcations as well as within bronchiolar epithelial cells, alveolar macrophages, and visceral pleural mesothelial cells. These findings are noteworthy, since the alveolar duct bifurcations are the sites of deposition of inhaled asbestos fibers and represent the locations where the earliest tissue response to inhaled asbestos fibers occurs (1, 25). In addition, nitrotyrosine immunoreactivity was observed within the cytoplasm of mesothelial cells lining the parietal pleura of the chest wall and the diaphragm. The parietal pleural location of the nitrotyrosine-positive foci in asbestosexposed animals possibly may have pathogenetic significance, since asbestos-related parietal pleural plaques are detected in similar anatomic locations in circumstances of human occupational exposure to asbestos $(1,28)$. In contrast, the lungs of

Figure 3 legend (Continued)

Original magnification, $\times 150$. $(E)$ There is positive immunostaining for nitrotyrosine within an aggregate of alveolar macrophages (arrow) as well as in the alveolar epithelium (arrowheads) and interstitial cells at an alveolar duct bifurcation of a chrysotile-exposed rat. Original magnification, $\times 100 .(F)$ There is only minimal immunoreactivity for nitrotyrosine in the bronchiolar epithelium of a sham-exposed rat. Original magnification, $\times 50$. 
A
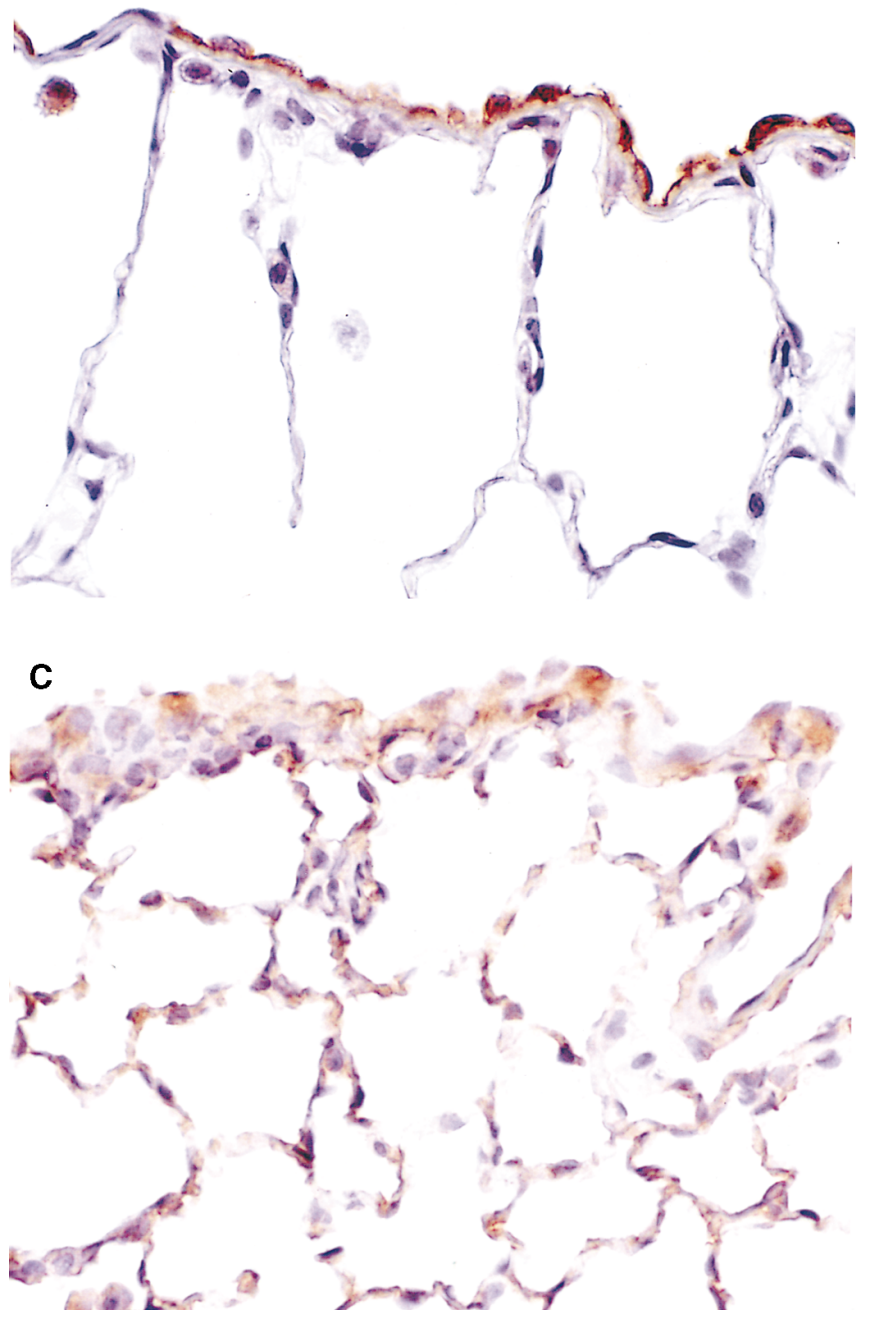

B

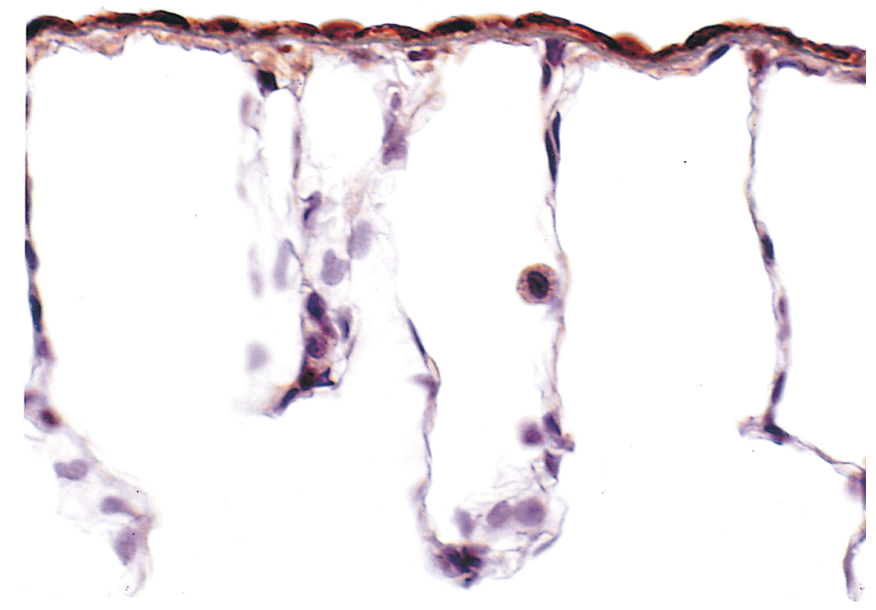

D

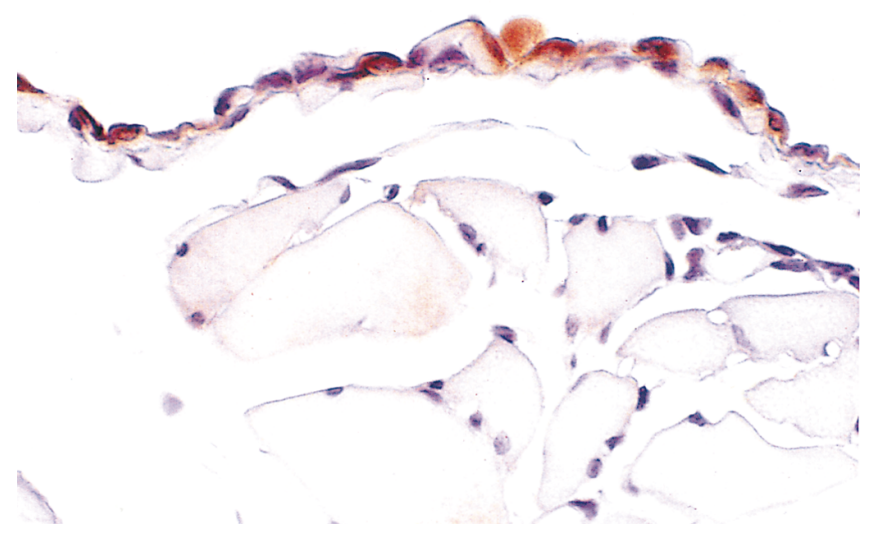

Figure 5. Immunoperoxidase staining for nitrotyrosine in sections from asbestos-exposed rats at $1 \mathrm{wk}(A, B$, and $D)$ and at $6 \mathrm{wk}(C)$ after the cessation of exposure. $(A)$ Immunoreactivity for nitrotyrosine is detected within the visceral pleural mesothelium and an occasional alveolar macrophage of a crocidolite-exposed rat. Original magnification, $\times 150$. (B) Similar immunoreactivity for nitrotyrosine is evident within the visceral pleural mesothelium of a chrysotile-exposed rat. Original magnification, $\times 150$. (C) Strong immunostaining for nitrotyrosine is observed in the visceral pleural mesothelium of a chrysotile-exposed rat. Original magnification, $\times 150$. (D) Strong immunostaining for nitrotyrosine is observed in the parietal pleural mesothelium of a chrysotile-exposed rat at $1 \mathrm{wk}$ after the cessation of exposure. Original magnification, $\times 150$.

sham-exposed rats manifested only faint, focal cytoplasmic immunoreactivity within bronchiolar epithelial cells and within occasional alveolar macrophages. Another important observation was the fact that nitrotyrosine immunoreactivity within the lung parenchyma and pleura was persistent, having been detected as soon as $1 \mathrm{wk}$ and for as long as $6 \mathrm{wk}$ after asbestos exposure had ceased.

Previous studies have demonstrated that nitration reactions may occur in the lungs after a variety of in vivo toxic insults such as in patients with adult respiratory distress syndrome (11) and in rats exposed to endotoxin (29), zymosan (12), or hyperoxia (11). These reactions have been attributed to the interaction of $\cdot \mathrm{NO}$ with $\mathrm{O}_{2}^{\overline{2}}$ at a rate constant of $6.7 \times$ $10^{9} \mathrm{M}^{-1} \mathrm{~s}^{-1}$ at $\mathrm{pH} 7.4$ to form $\mathrm{ONOO}^{-}$(30) and have been observed in circumstances associated with cytokine-induced inflammation. There is evidence that the nitration yield may be increased via the formation of the nitrosoperoxycarbonate an- ion $\left(\mathrm{O}=\mathrm{N}-\mathrm{OOCO}_{2}^{-}\right)$from physiologic concentrations of $\mathrm{CO}_{2}$ and bicarbonate, thereby enhancing the reactivity of $\mathrm{ONOO}^{-}$ (31).

Significant pulmonary sources of $\cdot \mathrm{NO} / \mathrm{ONOO}^{-}$include activated macrophages (32), neutrophils (33), type II pneumocytes (34), and airway cells (34). It is now well-recognized that upregulated iNOS activity and $\cdot \mathrm{NO} / \mathrm{ONOO}^{-}$formation have been detected in rats (12) as well as patients with inflammatory lung disease $(35,36)$. Thus, it is pertinent that asbestos exposure in clinical settings as well as experimental asbestos inhalation models in the rat are characterized by protracted macrophage accumulations at sites of asbestos fiber deposition $(1,26,28)$ and upregulated secretion of the cytokines, TNF- $\alpha$, IL-1 $\beta$, and interferon- $\gamma$, which induce iNOS activation (3739). Moreover, chrysotile and amosite inhalation can induce proliferative lesions in rat airway and proximal alveolar epithelium $(40,41)$. Additionally, both chrysotile and crocidolite 


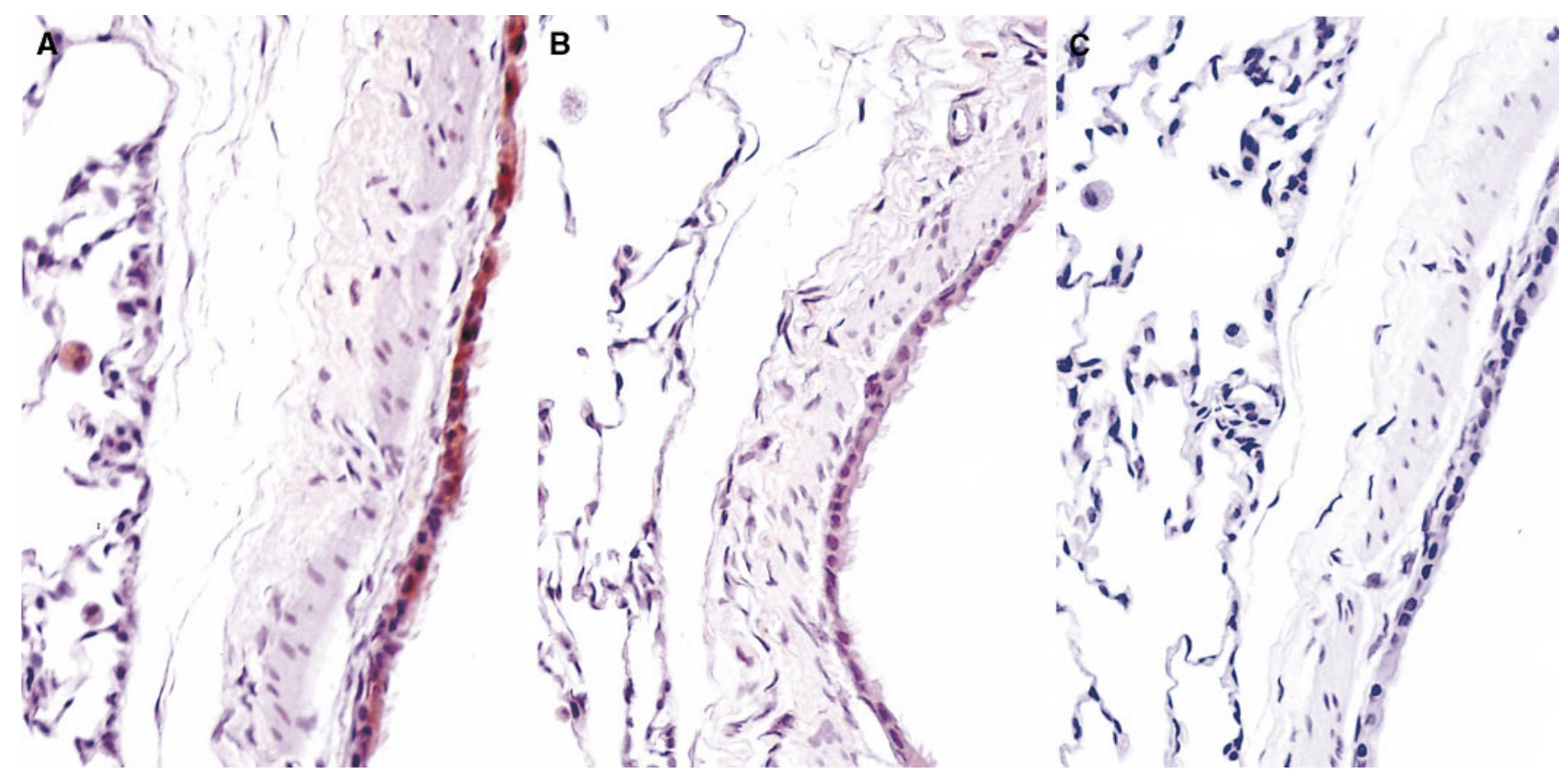

Figure 6. Experiments demonstrating immunospecificity of primary antibody for nitrotyrosine in the lung from a chrysotile-exposed rat at 1 wk after the cessation of exposure. (A) Strong immunoreactivity for nitrotyrosine is expressed in the bronchiolar epithelium and alveolar macrophages when the primary antibody to nitrotyrosine was used. Original magnification, $\times 100$. $(B)$ In this serial section, no immunostaining was observed when the primary antibody to nitrotyrosine was replaced with $10 \%$ normal rabbit serum. Original magnification, $\times 100$. $(C)$ Immunoreactivity for nitrotyrosine was completely blocked by coincubation of the primary antibody to nitrotyrosine with $10 \mathrm{mM}$ nitrotyrosine. Original magnification, $\times 100$.

inhalation in the rat have been shown to induce a persistent macrophage inflammatory response within the pleural space associated with enhanced pleural macrophage TNF- $\alpha$ secretion (17). Therefore, the findings in the current study of iNOS activation and nitrotyrosine formation are likely to reflect the consequences of asbestos-induced pleuro-pulmonary cytokine activation.

At first glance, our levels of nitrated tyrosines in asbestosexposed rats are small. However, it should be noted that these results are normalized to total lung protein whereas our immunocytochemical data show extensive nitration mainly in airway and mesothelial cells. Levels of lung nitrotyrosine detected in our studies are comparable with those reported by Leeuwenburgh et al. in human plasma-derived low-density lipoprotein (42), by Shigenaga et al. in normal rat serum (43), and by Khan et al. in human serum albumin and $\mathrm{ONOO}^{-}$-treated low-density lipoprotein in plasma (44). However, these concentrations are $\sim 1-2$ orders of magnitude less than those measured in atherosclerotic plaques (42) and the peritoneal exudate of zymosan-injected rats (43).

Although it is not possible to determine whether our observations are causally related to the induction of asbestos-related fibrosis and carcinogenesis, there is strong circumstantial support for this contention. Firstly, both chrysotile and crocidolite fibers were shown recently to induce the formation of $\mathrm{ONOO}^{-}$ in IL-1 $\beta$-containing rat pleural mesothelial cell cultures, an effect that showed a good correlation with the cytotoxic action of those fibers on the cultured cells (14). The detection of protracted elevations of LDH levels in the BAL fluids of crocidolite- and chrysotile-exposed rats is consistent with these obser- vations (19). $\mathrm{ONOO}^{-}$is a potent oxidant that can initiate cell injury via oxidation of protein sulfhydryl moieties and lipid peroxidation (30) and by decreasing oxygen consumption and sodium uptake through amiloride-sensitive sodium channels $(45,46)$. Recently, it also has been demonstrated that $\mathrm{ONOO}^{-}$ can activate the enzyme poly (ADP-ribose) polymerase in human pulmonary epithelial cells, thereby inducing cellular energy depletion, inhibition of mitochondrial respiration, and increased cellular permeability (47). Notably, both chrysotile and crocidolite fibers were shown to induce poly (ADP-ribose) polymerase activation in rat pleural mesothelial cells (48). Additionally, there is evidence that $\mathrm{ONOO}^{-}$can mediate apoptosis in diverse inflammatory settings $(49,50)$. This may have significance for asbestos-related injury, since two recent studies have documented that asbestos fibers can induce apoptosis in pleural mesothelial cells $(51,52)$ and, in one of them, apoptosis was abrogated by a poly (ADP-ribose) polymerase inhibitor (52).

Several studies have shown that $\mathrm{ONOO}^{-}$-induced protein nitration may compromise protein function and mediate tissue injury. In one, nitration of tyrosine residues of human IgG abrogated their C1q-binding activity (53). Tyrosine nitration also has been shown to inhibit protein phosphorylation by tyrosine kinases, thus interfering with signal transduction mechanisms (54), and to inhibit the assembly of neurofilament subunits by nitrating a major structural protein of motor neurons (55). Whatever mechanisms may be involved, there are strong parallels between the findings in our rodent model of asbestosis and those of Saleh et al. in patients with idiopathic pulmonary fibrosis (35). These authors reported the existence of signifi- 
cant amounts of nitrotyrosine and iNOS in macrophages, neutrophils, and alveolar epithelial cells of patients with idiopathic pulmonary fibrosis and proposed that RNS may be responsible for the generation of fibrosis. The exact mechanisms whereby this occurs have not been identified.

It is conceivable that activation of iNOS within alveolar and pleural macrophages may be linked to the fibroproliferative and neoplastic effects of asbestos. In this regard, it is pertinent that $\cdot \mathrm{NO}$ has been shown to upregulate the release of IL-1 and TNF- $\alpha$ from mouse peritoneal macrophages (56). Also, by mobilizing iron from crocidolite fibers or from asbestos bodies, - NO can produce DNA strand breakages (10) and DNA base modification (15). Moreover, rat pleural mesothelial cells stimulated with cytokines and LPS were found to generate potentially carcinogenic $N$-nitrosating compounds from •NO (57). Therefore, the detection in the present study of strong immunostaining for nitrotyrosine within the airway epithelium and visceral and parietal pleural mesothelium of asbestos-exposed rats may have added significance, since these epithelial cells are the progenitor cells for bronchogenic carcinoma and malignant pleural mesothelioma, respectively.

In summary, this study has demonstrated for the first time that inhaled asbestos fibers, which are recognized fibrogenic and carcinogenic agents, can induce the formation of RNS in the rat pleura and lung parenchyma. It is also noteworthy that the biologic effects of chrysotile were found to be equivalent to or greater than those of crocidolite asbestos in this regard. Therefore, our findings underscore the pathogenic potential of chrysotile to inflict pleuro-parenchymal injury $(4,5)$. Furthermore, the induction of RNS by both chrysotile and crocidolite fibers in vivo may provide an alternative mechanism of asbestos-induced injury to that thought to be induced by Fenton reactions.

\section{Acknowledgments}

This study was supported by grants HL-54196, HL-31197, and HL51173 from the National Institutes of Health and by grant N00001497-1-0309 from the Office of Naval Research. Dr. Zhu was partially supported by T32 HL-07553.

\section{References}

1. Kagan, E. 1985. Current perspectives in asbestosis. Ann. Allergy. 54:464-474. 2. Mossman, B.T., D.W. Kamp, and S.A. Weitzman. 1996. Mechanisms of carcinogenesis and clinical features of asbestos-associated cancers. Cancer Invest. $14: 466-480$

3. Gibbs, A.R. 1990. Role of asbestos and other fibres in the development of diffuse malignant mesothelioma. Thorax. 45:649-654.

4. Smith, A.H., and C.C. Wright. 1996. Chrysotile asbestos is the main cause of pleural mesothelioma. Am. J. Ind. Med. 30:252-266.

5. Stayner, L.T., D.A. Dankovic, and R.A. Lemen. 1996. Occupational exposure to chrysotile asbestos and cancer risk: a review of the amphibole hypothesis. Am. J. Public Health. 86:179-186.

6. Goodglick, L.A., and A.B. Kane. 1990. Cytotoxicity of long and short crocidolite asbestos fibers in vitro and in vivo. Cancer Res. 50:5153-5163.

7. Mossman, B.T., J.P. Marsh, A. Sesko, S. Hill, M.A. Shatos, J. Doherty, J. Petruska, K.B. Adler, D. Hemenway, R. Mickey, et al. 1990. Inhibition of lung injury, inflammation, and interstitial pulmonary fibrosis by polyethylene-conjugated catalase in a rapid inhalation model of asbestosis. Am. Rev. Respir. Dis. 141:1266-1271

8. Mossman, B.T., P. Surinrut, B.T. Brinton, J.P. Marsh, N.H. Heintz, B. Lindau-Shepard, and J.B. Shaffer. 1996. Transfection of a manganese-containing superoxide dismutase gene into hamster tracheal epithelial cells ameliorates asbestos-mediated cytotoxicity. Free Rad. Biol. Med. 21:125-131.

9. Campbell, W.J., C.W. Huggins, and A.G. Wylie. 1980. Chemical and physical characterization of amosite, chrysotile, crocidolite, and non-fibrous tremolite for oral ingestion studies by the National Institute for Environmental
Health Sciences. U.S. Department of the Interior, Washington, D.C. 63 pp.

10. Lund, L.G., and A.E. Aust. 1992. Iron mobilization from crocidolite asbestos greatly enhances crocidolite-dependent formation of DNA single-strand breaks in X174 RFI DNA. Carcinogenesis. 13:637-642.

11. Haddad, I.Y., G. Pataki, P. Hu, C. Galliani, J.S. Beckman, and S. Matalon. 1994. Quantitation of nitrotyrosine levels in lung sections of patients and animals with acute lung injury. J. Clin. Invest. 94:2407-2413.

12. Setoguchi, K., M. Takeya, T. Akaike, M. Suga, R. Hattori, H. Maeda, M. Ando, and K. Takahashi. 1996. Expression of inducible nitric oxide synthase and its involvement in pulmonary granulomatous inflammation in rats. Am. $J$. Pathol. 149:2005-2022.

13. Thomas, G., T. Ando, K. Verma, and E. Kagan. 1994. Asbestos fibers and interferon- $\gamma$ up-regulate nitric oxide production in rat alveolar macrophages. Am. J. Respir. Cell Mol. Biol. 11:707-715.

14. Choe, N., S. Tanaka, and E. Kagan. 1998. Asbestos fibers and interleukin-1 up-regulate the formation of reactive nitrogen species in rat pleural mesothelial cells. Am. J. Respir. Cell Mol. Biol. In press.

15. Chao, C.-C., S.-H. Park, and A.E. Aust. 1996. Participation of nitric oxide and iron in the oxidation of DNA in asbestos-treated human lung epithelial cells. Arch. Biochem. Biophys. 326:152-157.

16. Mossman, B.T., Y.P. Janssen, J.P. Marsh, A. Sesko, M.A. Shatos, J. Doherty, K.B. Adler, D. Hemenway, R. Mickey, P. Vacek, et al. 1991. Development and characterization of a rapid-onset rodent inhalation model of asbestosis for disease prevention. Toxicol. Pathol. 19:412-418.

17. Choe, N., S. Tanaka, W. Xia, D.R. Hemenway, V.L. Roggli, and E. Kagan. 1997. Pleural macrophage recruitment and activation in asbestos-induced pleural injury. Environ. Health Perspect. 105:1257-1260.

18. Selikoff, I.J., and D.H.K. Lee. 1978. Asbestos and Disease. Academic Press, New York. 549 pp.

19. Kagan, E., Y. Oghiso, and D.-P. Hartmann. 1983. The effects of chrysotile and crocidolite asbestos on the lower respiratory tract: analysis of bronchoalveolar lavage constituents. Environ. Res. 32:382-397.

20. Thomas, G., and P.W. Ramwell. 1988. Vasodilatory properties of monoL-arginine-containing compounds. Biochem. Biophys. Res. Commun. 154:332-338.

21. Beckmann, J.S., Y.Z. Ye, P.G. Anderson, J. Chen, M.A. Accavitti, M.M. Tarpey, and C.R. White. 1994. Extensive nitration of protein tyrosines in human atherosclerosis detected by immunohistochemistry. Biol. Chem. HoppeSeyler. 375:81-88.

22. Beelen, R.H.J., I.L. Eestermans, E.A. Döpp, and C.D. Djikstra. 1987 Monoclonal antibodies ED1, ED2, and ED3 against rat macrophages: expression of recognized antigens in different stages of differentiation. Transplant. Proc. 19:3166-3170.

23. Zhu, S., I.Y. Haddad, and S. Matalon. 1996. Nitration of surfactant protein A (SP-A) tyrosine residues results in decreased mannose binding ability. Arch. Biochem. Biophys. 333:282-290.

24. Sokolovsky, M., J.F. Riordan, and B.L. Vallee. 1966. Tetranitromethane. A reagent for the nitration of tyrosyl residues in proteins. Biochemistry. 5:3582-3589.

25. Brody, A.R., L.H. Hill, B. Adkins, Jr., and R.W. O'Connor 1981 Chrysotile asbestos inhalation in rats. Deposition pattern and reaction of alveolar epithelium and pulmonary macrophages. Am. Rev. Respir. Dis. 123:670-679.

26. Oghiso, Y., E. Kagan, and A.R. Brody. 1984. Intrapulmonary distribution of inhaled chrysotile and crocidolite asbestos: ultrastructural features. $\mathrm{Br}$. J. Exp. Pathol. 65:467-484

27. Haddad, I.Y., J.P. Crow, P. Hu, Y. Ye, J. Beckman, and S. Matalon. 1994. Concurrent generation of nitric oxide and superoxide damages surfactant protein A. Am. J. Physiol. 267:L242-L249.

28. Craighead, J.E., J.L. Abraham, A. Churg, F.H.Y. Green, J. Kleinerman, P.C. Pratt, T.A. Seemayer, V. Vallyathan, and H. Weill. 1982. The pathology of asbestos-associated diseases of the lungs and pleural cavities: diagnostic criteria and proposed grading schema. Arch. Pathol. Lab. Med. 106:544-596.

29. Wizemann, T.M., C.R. Gardner, J.D. Laskin, S. Quinones, S.K. Durham, N.L. Goller, S.T. Ohnishi, and D.L. Laskin. 1994. Production of nitric oxide and peroxynitrite in the lung during acute endotoxemia. J. Leukoc. Biol. 56:759-768.

30. Radi, R., J.S. Beckman, K.M. Bush, and B.A. Freeman. 1991. Peroxynitrite oxidation of sulfhydryls. J. Biol. Chem. 266:4244-4250.

31. Gow, A., D. Duran, S.R. Thom, and H. Ischiropoulos. 1996. Carbon dioxide enhancement of peroxynitrite-mediated protein tyrosine nitration. Arch. Biochem. Biophys. 333:42-48.

32. Ischiropoulos, H., L. Zhu, and J.S. Beckman. 1992. Peroxynitrite formation from macrophage-derived nitric oxide. Arch. Biochem. Biophys. 298:446-451.

33. Carreras, M.C., G.A. Pargament, S.D. Catz, J.J. Poderoso, and A. Boveris. 1994. Kinetics of nitric oxide and hydrogen peroxide production and formation of peroxynitrite during the respiratory burst of human neutrophils. FEBS Lett. 341:65-68.

34. Kobzik, L., D.S. Bredt, C.J. Lowenstein, J. Drazen, B. Gaston, D. Sugarbaker, and J.S. Stamler. 1993. Nitric oxide synthase in human and rat lung: immunocytochemical and histochemical localization. Am. J. Respir. Cell Mol. Biol. 9:371-377.

35. Saleh, D., P.J. Barnes, and A. Giaid. 1997. Increased production of the potent oxidant peroxynitrite in the lungs of patients with idiopathic pulmonary 
fibrosis. Am. J. Respir. Crit. Care Med. 155:1763-1769.

36. Sittipunt, C., K.P. Steinberg, S. Matalon, J.T. Ruzinski, R.B. Goodman, L.D. Hudson, and T.R. Martin. 1998. Increased levels of nitric oxide end products (nitrate and nitrite) in BALF from patients with acute respiratory distress syndrome. Am. J. Respir. Crit. Care Med. 157:A682. (Abstr.)

37. Robinson, B.W.S., A.H. Rose, A. Hayes, and A.W. Musk. 1988. Increased pulmonary gamma interferon production in asbestosis. Am. Rev. Respir. Dis. 138:278-283.

38. Zhang, Y., T.C. Lee, B. Guillemin, M.-C. Yu, and W.N. Rom. 1993. Enhanced IL-1 and tumor necrosis factor-release and messenger RNA expression in macrophages from idiopathic pulmonary fibrosis or after asbestos exposure. J. Immunol. 150:4188-4196.

39. Hartmann, D.P., M.M. Georgian, Y. Oghiso, and E. Kagan. 1984. Enhanced interleukin activity following asbestos inhalation. Clin. Exp. Immunol. 55:643-650.

40. Coin, P.G., A.R. Osornio-Vargas, V.L. Roggli, and A.R. Brody. 1996. Pulmonary fibrogenesis after three consecutive inhalation exposures to chrysotile asbestos. Am. J. Respir. Crit. Care Med. 154:1511-1519.

41. Donaldson, K., D.M. Brown, B.G. Miller, and A.R. Brody. 1995. Bromo-deoxyuridine (BRDU) uptake in the lungs of rats inhaling amosite asbestos or vitreous fibres at equal airborne fibre concentrations. Exp. Toxicol. Pathol. 47:207-211.

42. Leeuwenburgh, C., M.M. Hardy, S.L. Hazen, P. Wagner, S. Oh-ishi, U.P. Steinbrecher, and J.W. Heinecke. 1997. Reactive nitrogen intermediates promote low density lipoprotein oxidation in human atherosclerotic intima. $J$. Biol. Chem. 272:1433-1436.

43. Shigenaga, M.K., H.H. Lee, B.C. Blount, S. Christen, E.T. Shigeno, H. Yip, and B.N. Ames. 1997. Inflammation and $\mathrm{NO}_{x}$-induced nitration: assay for 3-nitrotyrosine by HPLC with electrochemical detection. Proc. Natl. Acad. Sci. USA. 94:3211-3216.

44. Khan, J., D.M. Brennan, N. Bradley, B. Gao, R. Bruckdorfer, and M. Jacobs. 1998. 3-nitrotyrosine in the proteins of human plasma determined by an ELISA method. Biochem. J. 330:795-801.

45. Bauer, M.L., J.S. Beckman, R.J. Bridges, C.M. Fuller, and S. Matalon. 1992. Peroxynitrite inhibits sodium uptake in rat colonic membrane vesicles. Biochem. Biophys. Acta. 1104:87-94.

46. Hu, P., H. Ischiropoulos, J.S. Beckman, and S. Matalon. 1994. Peroxyni- trite inhibition of oxygen consumption and sodium transport in alveolar type II cells. Am. J. Physiol. 266:L628-L634.

47. Szabó, C., C. Saunders, M. O’Connor, and A.L. Salzman. 1997. Peroxynitrite causes energy depletion and increases permeability via activation of poly(ADP-ribose) synthetase in pulmonary epithelial cells. Am. J. Respir. Cell Mol. Biol. 16:105-109.

48. Dong, H.Y., A. Buard, F. Lévy, A. Renier, F. Laval, and M.-C. Jaurand. 1995. Synthesis of poly(ADP-ribose) in asbestos treated rat pleural mesothelial cells in culture. Mut. Res. 331:197-204.

49. Szabolcs, M., R.E. Michler, X. Yang, W. Aji, D. Roy, E. Athan, R.R. Sciacca, O.P. Minanov, and P.J. Cannon. 1996. Apoptosis of cardiac myocytes during cardiac allograft rejection. Relation to induction of nitric oxide synthase. Circulation. 94:1665-1673.

50. Ford, H., S. Watkins, K. Reblock, and M. Rowe. 1996. The role of in flammatory cytokines and nitric oxide in the pathogenesis of necrotizing enterocolitis. J. Pediatr. Surg. 32:275-282.

51. BéruBé, K.A., T.R. Quinlan, H. Fung, J. Magae, P. Vacek, D.J. Taatjes, and B.T. Mossman. 1996. Apoptosis is observed in mesothelial cells after exposure to crocidolite asbestos. Am. J. Respir. Cell Mol. Biol. 15:141-147.

52. Broaddus, V.C., L. Yang, L.M. Scavo, J.D. Ernst, and A.M. Boylan. 1996. Asbestos induces apoptosis of human and rabbit pleural mesothelial cells via reactive oxygen species. J. Clin. Invest. 98:2050-2059.

53. McCall, M.N., and S.B. Easterbrook-Smith. 1989. Comparison of the role of tyrosine residues in human $\mathrm{IgG}$ and rabbit $\mathrm{IgG}$ in binding of complement subcomponent C1q. Biochem. J. 257:845-851.

54. Gow, A.J., D. Duran, S. Malcolm, and H. Ischiropoulos. 1996. Effects of peroxynitrite-induced protein modification on tyrosine phosphorylation and degradation. FEBS Lett. 385:63-66.

55. Crow, J.P., Y.Z. Ye, M. Strong, M. Kirk, S. Barnes, and J.S. Beckman. 1997. Superoxide dismutase catalyzes nitration of tyrosines by peroxynitrite in the rod and head domains of neurofilament-L. J. Neurochem. 69:1945-1953.

56. Marcinkiewicz, J., A. Grabowska, and B. Chain. 1995. Nitric oxide upregulates the release of inflammatory mediators by mouse macrophages. Eur. $J$. Immunol. 25:947-951.

57. Owens, M.W., S.A. Milligan, and M.B. Grisham. 1995. Nitric oxidedependent- $N$-nitrosating activity of rat pleural mesothelial cells. Free Rad. Res. 23:371-378. 